Fig. 5. The same. Fragment of fibre in a thin slice, mounted in Canada balsam, as seen by transmitted light under a microscopic power of about 125 diameters. a, shaft of axial spicule (? of a colossal radiate) ; $b$, short conical arm, or spur, projecting from it, showing in this instance that it is spiniferous; $c$, edges of the laminæ, forming the fibre outside the axial spicule, crenulated.

Fig. 6. The same. Showing that the outer layer of the fibre may be tubercled. $a$, axial spicule; $b$, edges of fibre-laminæ.

Fig. 7. The same. Showing two rays or spurs near each other on the same axial spicule. $a$, axial spicule and spurs; $b$, edge of fibrelamina.

Fig. 8. The same. Showing that the fibre-laminæ may also project spurs. $a$, axial spicule, bearing one spur; $b$, fibre-laminæ, bearing two spurs near each other.

Fig. 9. The same. Showing that the fibre-lamina follows the form of the spur on the axial spicule. $a$, axial spicule and spur; $b$, fibrelamina.

Fig. 10. The same. Showing that the axial spicule is composed of concentric laminæ. $a$, axial spicule; $b$, fibre-laminæ.

Fig. 11. The same. Showing the arms of a tri- or quadriradiate spicule in the axis of the fibre. $a$, radiate spicule; $b$, fibre-lamina.

Fig. 12. The same. Showing spurs and crenulated laminæ close to the axial spicule. $a$, axial spicule; $b$, fibre-lamina.

Fig. 13. Levicetta clathrata, n. sp., on a foliaceous coralline. a, Calcisponges. Nat. size.

Fig. 14. The same. Magnified eight diameters, to show the vermiculoreticulation of the clathrous structure on the surface. $a$, osculum.

Fig. 15. The same. Surface of vermiculo-reticulation, to show that it is composed of spicule No.16, covered in by No. 17. a a, summits of No. $16 ; b b$, lateral view of the same; $c c$, No. 17 .

Fig. 16. The same. Colossal triradiate or tripod spicule. Lateral view.

Fig. 17. The same. Smaller triradiate of the staple kind. Horizontal view. (Both of the average largest size, magnified equally, to show their relative dimensions.)

IV.-On Specimens of the Gephyrean Hamingia arctica, Kor. and Dan., from the Hardanger.Fjord. By E. RAY Lankester, M.A., F.R.S., Professor in University College, London.

In the 'Zoology (Gephyrea) of the Norwegian North-Atlantic Expedition,' published at Christiania in 1881, the distinguished Norwegian naturalists Koren and Danielssen, who have so long and so well worked together, describe, amongst other interesting novelties, a very remarkable Gephyrean allied to Bonellia, of which a single specimen came into their hands, having been dredged two hundred miles north of the North Cape. They gave to this the name Hamingia arctica. Later in the same year (1881) Dr. Horst, of Leyden, described (Niederl. Archiv für Zoologie, Supplementband i.) 
two specimens of Hamingia, placed in his hands by the eommittee of the "Barents" Dutch Arctic expedition, which were obtained in very nearly the same latitude as that described by Koren and Danielssen. Dr. Horst was able to add some particulars as to the vascular system and alimentary canal to the very precise and full account of the anatomy given by Koren and Danielssen. He has, however, without assigning any definite reasons, given to his specimens a new specific name "glacialis." There is, it seems to me, no ground for supposing that Dr. Horst's specimens belong to a new species.

The summary of characters given by Koren and Danielssen is as follows. It must be remembered that the conclusions of the Norwegian zoologists are derived from the study of a single specimen preserved in spirit.

\section{Generic Characters.}

"Body cylindrical; mouth at the anterior extremity nearest the ventral surface. Anal opening in the centre of the posterior extremity. A lunate somewhat prominent fold round the mouth (rudimentary proboscis). On the anterior portion of the ventral surface two long, cylindrical papillæ, having each at the apex a round aperture for the efferent duct of the corresponding uterus. No bristles.

"The intestinal canal with numerous circumvolutions, but no spiral coil ; it disembogues into a cloaca, from both sides of which issues a ramifying glandular apparatus.

"The central nervous chord smooth, destitute of nodes or ganglions.

"One ovary protruding along the nervous chord in the posterior half of the perivisceral cavity. tube.

"Two uteri, each with an efferent duct and funnel-shaped

"The male as yet unobserved."

\section{Specific Characters.}

"Body cylindrical, smooth, 120 millim. long, 20 millim. thick, repeatedly changing its form as it contracts and expands. Colour a lighter or darker grassy green. Buccal disk whitish yellow ; the arcuate papillæ on the ventral surface greenish with whitish yellow extremities."

Occurrence of new Specimens.- In the month of August of this year (1882), which I spent in dredging at Lervik, at the mouth of the Hardanger Fjord, in company with the Rev. Alfred Norman and Mr. A. G. Bourne, a specimen of Hamingia arctica was brought up in the dredge. The specimen was dredged on a rocky bottom, at about 40 fathoms depth, just 
outside the harbour, south of the lighthouse island. The spot was nearly the same as that where, two years previously, Mr. Norman had dredged "a Bonellia-like Gephyrean," which he has had the great kindness to place in my hands for examination since our return to England. This specimen also proves to be a Hamingia.

Proboscis or Frontal Hood.-At first sight I was inclined to suppose that the Gephyrean dredged this summer was not Hamingia, but a Thalassema. It was about half the size of Koren's and Danielssen's specimen, of a bright apple-green colour, and had a long contractile proboscis resembling closely that of Thalassema and Echiurus. The proboscis, when extended, was as long as the body, each measuring about an inch and a half in length when thus extended. As is shown above, Koren and Danielssen have made the absence of a proboscis or frontal hood a leading character of their genus Hamingia. Dr. Horst describes one of his specimens as possessing a rudimentary proboscis. As is well known, the proboscis or frontal hood is very readily broken away in Echiurus; and its absence has before now led to erroneous conclusions. Quite recently Sluiter has shown that Sternaspis is normally provided with a large bilobed frontal lobe corresponding to the proboscis of Echiurus, though it has been broken off in every specimen hitherto described, and its existence not even suspected.

Shape of Body.-The movements of the body and its alterations of form in the living state closely resembled the movements and changes of shape of Thalassema neptuni, Gärtner, which I have observed in large numbers on the coast of Devonshire. Indeed I should have concluded from the examination of external characters that the specimen was a green-coloured Thalassema, differing only from other Thalassemee in the absence of genital seta.

Uterine Pouches and Ova.-On dissection, however, the identity of our specimen with Hamingia became quite certain. In place of the four or six uterine sacs present in Thalassema there was a single pair present, having very delicate transparent walls, unlike those of Thalassema. The ova and the ovaries were unlike those of Thalassema, and presented the same peculiarities as those of Bonellia, and thus corresponded with the description of Koren and Danielssen.

Cloacal Trees.-Further the "cloacal trees," or "nephridia," were found to differ from the simple pouches which occur in Thalassema, and to agree with those of Bonellia in being branched, as described and figured by Koren and Danielssen in their specimen.

Red Corpuscles of Celom.-One important fact I was able: 
to add to the description of Koren and Danielssen besides the existence of a Thalassema-like proboscis, owing to my specimen being in the fresh state. This was the existence in the liquid of the body-cavity of corpuscles impregnated with hæmoglobin. These corpuscles were so abundant as to give the perivisceral fluid a bright blood-red colour. I had previously (Zool. Anzeiger, 1881, no. 87) published a similar observation with regard to Thalassema neptuni. In Bonellia I can state, from my own observations made at Naples in 1874, that the perivisceral fluid is colourless. It also appears to be colourless in Echiurus.

Mr. Norman's Specimen.-The second specimen of Hamingia from Lervik, namely that dredged by Mr. Norman two years ago, came into my hands well preserved in spirit. It was a little larger than that dredged this summer. It had suffered in regard to the proboscis, as is so usual in preserved specimens of the Echiuridæ*. A very short remnant of the base of the proboscis only was preserved, thus agreeing with the specimens studied by Koren and Danielssen and by Dr. Horst.

Single Uterine Pouch.-The most remarkable fact about this second specimen was that only one genital papilla and one genital orifice was present instead of two, as in all the other specimens of Hamingia described. Corresponding to this single orifice was a single uterine pouch. This abnormality brings us to a condition which is normal in Bonellia, where only one uterine pouch is found. At the same time it is worth noting that the very delicate hyaline walls of the uterine pouch of Hamingia (though muscular) differ from the thick dense walls of that of Bonellia, as also does the internal orifice or funnel. Abnormalities in the number of uterine or spermatic pouches are not uncommonly to be observed in Thalassema neptuni.

The Male of Hamingia.-In this second specimen of $\mathrm{Ha}$ mingia (Mr. Norman's) I was fortunate enough to discover the male sex. As in Bonellia, so in Hamingia the male is a minute worm-like creature which lives as a parasite upon and in the female. I found five of these minute males (each $\frac{1}{12}$ inch long) within the dilated pharynx of the female Hamingia. I did not find any males in the uterine pouch, which was distended by fully formed eggs and was nearly as long as the whole body.

* I may mention in illustration of this fact, and as explaining the mistake made by Koren and Danielssen, that in a collection of twenty wellpreserved specimens of Echiurus unicinctus from Japan, brought home by the 'Challenger,' not one had the proboscis in place; all showed a crescentic ridge whence the proboscis had been broken away, as in Koren and Danielssen's Hamingia. 
The males closely resemble those of the "Bonellia minor" of Marion, as figured by Vejdowsky in a woodcut in his memoir "Ueber dieEibildung und dieMännchen von Bonelliaviridis, Rol." (Zeitschr. wiss.Zool. vol. xxx. p. 495). Every one of my five male Hamingiae is provided with a pair of long recurved hooks (woodcut). The surface of the body is uniformly ciliated. Beyond this the condition of the specimens does not enable me to give any details, excepting that there is a spermatic pouch which opens in front of the hooklets.

The existence of a hookbearing male is of special interest in relation to the fact that Hamingia stands alone among the Echiuroidea in having no genital setæ near the genital papillæ of the female.

It is also of importance as tending toremove any lingering doubt (such as was lately suggested by Greeff') as to the nature of the organisms described by Kowalevsky as the males of Bonellia.

Further, it is hereby shown that Hamingia, which differs in so many respects from $B o$ nellia, and tends rather to agree with Thalassema, is, in respect of its male, in the same case as the former genus.

Characters of Hamingia, Thalassema, and Bonellia.-I will now briefly compare the three genera Hamingia, Thalassema, and Bonellia, as to some of their chief characteristics. This is most easily done by means of the tabular statement here following.

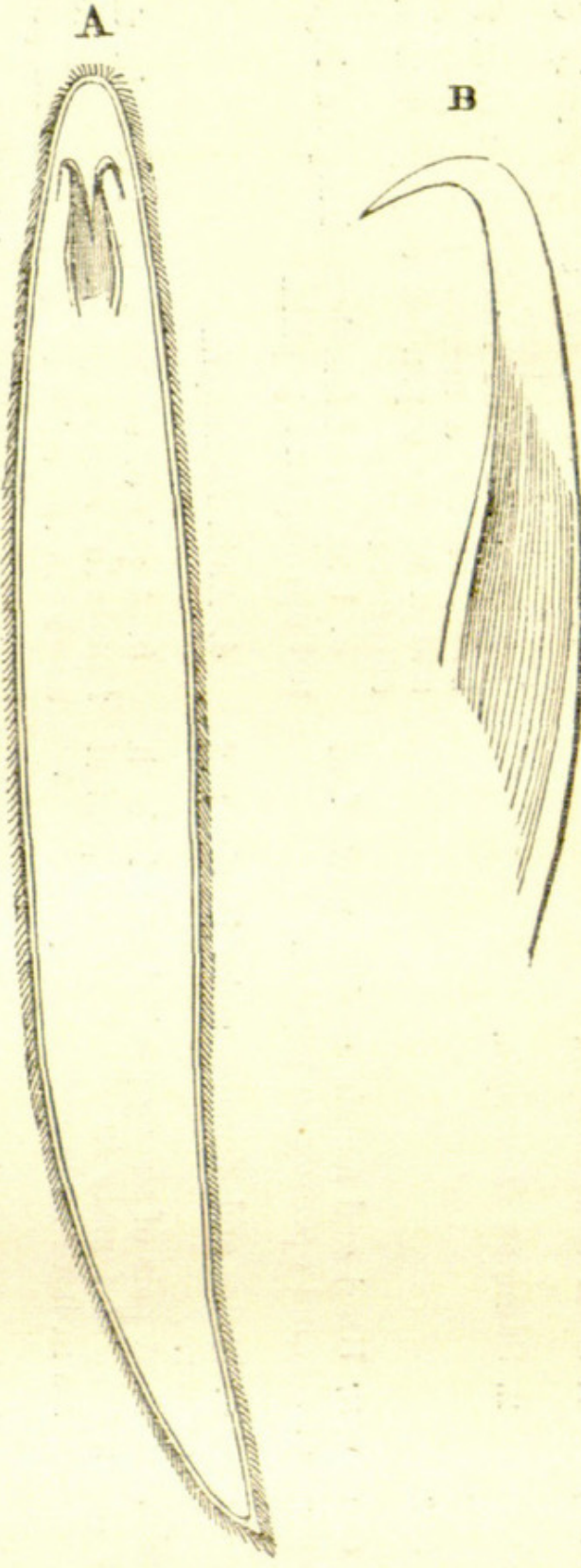

Male of Hamingia arctica.

A. Whole animal, showing the two hooked setæ and the ciliated cuticle. Size $\frac{1}{12}$ inch long.

B. A single seta, more highly magnified. 


\section{Hamingia.}

1. Shape of body elongate, cylindrical, tapering towards anus.

2. Frontal hood (so-called proboscis) as long as body when stretched, tapering towards the free end, narrow and troughlike.

3. Uteri and female genital pores one or two, each opening on a well-marked papilla.

4. Male exceedingly minute, parasitic on female.

5. Genital setæ absent in the female, present posteriorly to the genital pore in the diminutive male.

6. Ova enclosed in a capsule of " follicle-cells" with a mass of nutrient cells attached,

7. Mature ovum divisible into an outer "nutrient" zone of vacuolated protoplasm and an inner denser protoplasm.

8. Uterine pouch or pouches when filled with eggs have delicate hyaline walls.

9. Internal opening of uterine pouch a plicated funnel with ciliated surface.

10. Anterior portion of pharynx dilated.

11. Cloacal nephridia divided into lobes or branches; nephrostomes mounted on long stalks.

12. Corpuscles of the perivisceral fluid coloured red by hæmoglobin.

Thalassema.

\section{BONELLIA.}

1. Same as Hamingia.

2. Same as Hamingia.

3: Uteri and female genital pores four or six, not opening on papillæ.

4. Males and females alike in size and colour.

5. A pair of strong genital setæ in both male and female in front of the genital pores in both male and female.

6. Ova not enclosed in follicle-cells (at any rate in $T$. neptuni!); nutrient cells attached.

7. Mature ovum more nearly homogeneous.

8. Uterine pouches even when distended have firm resistant walls.

9. As in Hamingia, except in some species, where it is drawn out into a long spiral trough.

10. Anterior portion of pharynx not dilated.

11. Cloacal nephridia simple sacs; nephrostomes on short stalks.

12. Same as in Hamingia in one species (T. neptuni); probably not so in others.
1. Shape of body subspherical, depressed on neural face.

2. Frontal hood much longer than the body, having a narrow trough-like stalk and a widely expanded caryophyllaceous anterior region.

3. Uterus and female genital pore single, not opening on a papilla.

\section{As in Hamingia.}

5. A pair of strong genital setæ in the female in front of the single genital pore; absent in the male of $B$. viridis and present as in Hamingia in $B$. minor.

6. Ova as in Hamingia.

7. Mature ovum as in Hamingia.

8. Wall of uterine pouch very solid.

9. Internal opening of uterine pouch firm, like the mouth and neck of a bottle.

\section{As in Hamingia.}

11. As in Hamingia.

12. Perivisceral fluid colourless. 
It is thus seen that Hamingia is really intermediate in its combination of characters between Bonellia and Thalassema.

Owing to their not having known the frontal hood or proboscis of Hamingia, Koren and Danielssen have somewhat overestimated the closeness of its relationship to Bonellia. On the whole it may be said that Hamingia has in internal organs a closer resemblance to Bonellia, in external shape and characters a closer resemblance to Thalassema.

The feature in which it is quite peculiar is in the absence of genital setæ in the female and the correlated existence of one or of two prominent papillæ which carry the genital pore or pores.

Summary.-The new facts which have been above recorded additional to the observations of Koren and Danielssen and Horst are briefly as follows:-

1. Hamingia arctica occurs on the Norwegian coast in latitude $60^{\circ}$, and at the comparatively small depth of 40 fathoms.

2. Hamingia has a frontal hood or proboscis resembling that of Thalassema, which is easily broken off as in Thalassema and Echiurus.

3. The corpuscles of the perivisceral fluid of Hamingia arctica are coloured red by hæmoglobin.

4. The male of Hamingia is a diminutive parasite living upon the female, as in the case of Bonellia; it is provided with a pair of large genital setæ, although such setæ are absent in the female.

5. Though usually there are two, yet there may be only one uterus and one genital pore, as in Bonellia.

\section{V.-The Theory of Mimicry and Mimicking Theories. By W. L. Distant.}

In the last issue of this Magazine (vol. x. p. 417) an article on the interesting subject of "Mimicry between Butterflies of Protected Genera," by Mr. R. Meldola, appears to be inspired by two short opinions of my own published elsewhere; and as the author has done me the honour of subjecting those views to a critical and somewhat trenchant analysis, it becomes necessary to point out that some of his strictures (in the present absence of supporting facts) appear to belong to the armoury of what may be called "forensic biology," and represent arguments which may ultimately prove to be both 


\section{$2 \mathrm{BHL}$ Biodiversity Heritage Library}

Lankester, E Ray. 1883. "IV.-On specimens of the Gephyrean Hamingia arctica, Kor. and Dan., from the Hardanger Fjord." The Annals and magazine of natural history; zoology, botany, and geology 11, 37-43.

https://doi.org/10.1080/00222938309459089.

View This Item Online: https://www.biodiversitylibrary.org/item/92742

DOI: https://doi.org/10.1080/00222938309459089

Permalink: https://www.biodiversitylibrary.org/partpdf/67882

\section{Holding Institution}

Missouri Botanical Garden, Peter H. Raven Library

\section{Sponsored by}

Missouri Botanical Garden

\section{Copyright \& Reuse}

Copyright Status: Public domain. The BHL considers that this work is no longer under copyright protection.

This document was created from content at the Biodiversity Heritage Library, the world's largest open access digital library for biodiversity literature and archives. Visit BHL at https://www.biodiversitylibrary.org. 